\title{
DEGRADASI ZAT WARNA NAPHTOL BLUE BLACK SECARA SONOLISIS DAN FOTOLISIS DENGAN PENAMBAHAN TIO $_{2}$-ANATASE
}

\author{
Safni $^{1}$, Maizatisna ${ }^{1}$, Zulfarman $^{1}$, T. Sakai ${ }^{2}$ \\ ${ }^{1}$ Laboratorium Kimia Analisis Instrumen, FMIPA Universitas Andalas \\ ${ }^{2}$ Department of Chemistry, Aichi Institute of Technology Toyota City, Japan
}

\begin{abstract}
Degradation of naphtol blue black dye had been done by sonolysis and photolysis with adding anatase$\mathrm{TiO}_{2}$. Sonolysis method were performed using an ultrasound with frequency $45 \mathrm{kHz}$, and photolysis using an irradiation of UV light $\lambda=359 \mathrm{~nm}$. The optimum condition for degradation of $6 \mathrm{mg} / \mathrm{L}$ naphtol blue black by sonolysis with addition of $0.1000 \mathrm{~g}$ anatase- $\mathrm{TiO}_{2}$ were found at $\mathrm{pH}=3.0$ and temperature $30 \pm$ $1{ }^{\circ} \mathrm{C}$. Percentage of degradation at $\mathrm{pH}$ and temperature optimum was $65.20 \%$ within 120 minutes treatment. Degradation of $6 \mathrm{mg} / \mathrm{L}$ naphtol blue black by photolysis with addition of $0.1000 \mathrm{~g}$ anatase- $\mathrm{TiO}_{2}$ was optimum at $\mathrm{pH}=3.0$ and percentage of degradation was $68.72 \%$ within 120 minutes irradiation without stirring. The combine of sonolysis and photolysis method simultaneously for degradation of naphtol blue black dye by adding anatase- $\mathrm{TiO}_{2}$, achieved $92.51 \%$ degradation after 60 minutes treatment.
\end{abstract}

Keywords : sonolysis, photolysis, naphtol blue black

\section{DAFTAR PUSTAKA}

1. Andayani, W., Sumartono, A., 1999, Aplikasi radiasi Pengion Dalam Penguraian Limbah Industri I. Radiolisis Larutan standar Zat warna reaktif Cibacron Violet 2R, Majalah Batan., Vol XXXII No.1/2, Januari/April.

2. Wang, J., Guo, B., Zhang, X., Zhang, Z., Han, J., Wu, J., 2005, Sonocatalytic Degradation of Methyl Orange in the Presence of $\mathrm{TiO}_{2}$ Catalysts and Catalytic Activity Comparison of Rutile and Anatase, $J$ Ultrasonics Sonochemistry., 12: 331-337.

3. Hiskia, A., Ecke, M., Troupis, A., Kokorakis, A., Hennig, H., Papaconstantinou, E., 2001, Sonolytic, and Photocatalytic Decomposition of Atrazin in Presence of Polyoxometalates, J. Environ. Sci. Technology., 35: 23582364.

4. Stock, N. L., Peller, J., Vinadgopal, K., Kamat, P. V., 2000, Combinative Sonolysis \& Photocatalysis for Textile Dye Degradation, J. Environ. Sci. Technology., 34: 1747-1750.
5. Peller, J., Wiest, O., Kamat, P. V., 2001, Sonolysis of 2,4-Dichlorophenoxyacetic Acid in Aqeous Solutions. Evidence for - OH-radical-Mediated Degradation, $J$. Phys. Chem. A., 105: 3176-3181.

6. Okitsu, K., Iwasaki, K., Yobiko, Y., Bandow, H., Nishimura, R., and Maeda, Y., 2005, Sonochemical Degradation of Azo Dyes in Aqueos Solution: a New Heterogeneous Kinetics Model Taking Into Account the Local Concentration of $\mathrm{OH}$ Radicals and Azo Dyes, $J$. Ultrasonic Sonochemistry., 12: 255-262.

7. Park, H., Choi, W., 2005, Photocatalytic Reactivities of Nafion-Coated $\mathrm{TiO}_{2}$ for The Degradation Charged Organic Compounds under UV or Visible Light, $J$. Phys, Chem. B., 109: 11667-11674.

8. Wang, J., Pan, Z., Zang, Z., Zang, X., Teng Ma, F.W., Jiang, Y., Wang, L., Xu, L., and Kang, P., 2005, Sonocatalytic Degradation of Methyl Parathion in the Presence of Nanometer and Ordinary Anatase Titanium Dioxide Catalysts and Comparison of their Sonocatalytic Abilities, J. Ultrasonic Sonochemistry. 
9. Dukkanci, M., and Gunduz, G., 2005, Ultrasonic Degradation of Oxalic Acid in Aqueos Solution, J. Ultrasonic Sonochemistry

10. Kuo, W. S., and Ho, P.H., 2001, Solar Photocatalytic Decolorization of Methylene Blue in Water, $J$. Chemosphere., 45: 77-83.
11. Selli, E., Bianchi, C. L., Pirola, C., Bartelli, M., 2005, Degradation of Methyl Tert-Buthyl Ether in Water: Effects of the Combination use of Sonolysis and Photocatalysis, $J$. Ultrasonic Sonochemistry., 12: 395-400. 